\title{
Molecular analysis of parapoxvirus from a spotted seal Phoca largha in Japan
}

\author{
Yoshito Ohno ${ }^{1}$, Yasuo Inoshima ${ }^{2, *}$, Ken Maeda $^{3}{ }^{,}$Naotaka Ishiguro $^{2}$ \\ ${ }^{1}$ Port of Nagoya Public Aquarium, 1-3 Minato-Machi, Minato-ku, Nagoya 455-0033, Japan \\ ${ }^{2}$ Laboratory of Food and Environmental Hygiene, Department of Veterinary Medicine, Gifu University, 1-1 Yanagido, \\ Gifu 501-1193, Japan \\ ${ }^{3}$ Laboratory of Veterinary Microbiology, Faculty of Agriculture, Yamaguchi University, 1677-1 Yoshida, \\ Yamaguchi 753-8515, Japan
}

\begin{abstract}
A spotted seal Phoca largha with nodular and scab lesions on the whole body was brought to an aquarium in Nagoya, Japan. We extracted DNA from the lesions and used the polymerase chain reaction (PCR) method for detecting orthopoxvirus and parapoxvirus DNA. Parapoxvirus but not orthopoxvirus DNA was detected. The partial nucleotide sequence of the envelope gene was determined from the PCR product, and the sequence was seen to be closely related to 2 parapoxvirus strains from spotted seals in Alaska, showing $100 \%$ identity at the amino acid level, with one nucleotide substitution. Virus-neutralizing (VN) antibody against canine distemper virus (CDV) was not detected in the serum, indicating that this individual was not infected with CDV or phocine distemper virus (PDV), which both have a high mortality rate for marine mammals. These results suggest that the lesions were caused by infection with pinniped parapoxvirus, and that the viruses spread and are maintained within the habitat range or populations of spotted seals from the Bering Sea to the Japan Sea. This is the first report of molecular analysis of parapoxvirus in marine mammals in Japan.
\end{abstract}

KEY WORDS: Parapoxvirus $\cdot$ Spotted seal $\cdot$ Molecular analysis $\cdot$ Marine mammals

\section{INTRODUCTION}

The genus Parapoxvirus belongs to the family Poxviridae $_{;}$it is a large, double-stranded and enveloped DNA virus. The genus Parapoxvirus includes orf virus, bovine papular stomatitis virus, pseudocowpox virus, and parapoxvirus of red deer in New Zealand (Damon 2007). Parapoxvirus infections are widespread in both domestic and wild ruminants worldwide. Pox-like dermal diseases have been observed in a wide variety of marine mammals, including bottlenose dolphins Tursiops truncatus, Pacific white-sided dolphins Lagenorhynchus obliquidens (Kohyama et al. 2010), Weddell seals Leptonychotes weddellii (Tryland et al. 2005), grey seals Halichoerus grypus (Nettleton et al. 1995), harbor seals Phoca vitulina (Müller et al. 2003), and Califor- nia sea lions Zalophus californianus (Nollens et al. 2006a). They involve nodular lesions (from 0.5 to $3.0 \mathrm{~cm}$ diam.) on the skin of the head, neck, and flippers, and on the mucosal surface of the mouth and nasal passages (Kennedy-Stoskopf 2001, Nollens et al. 2006b), similar to the lesions seen on terrestrial mammals. Although some lesions persist for months, they are usually self-limiting and regress after about $4 \mathrm{wk}$ (Gulland et al. 2001). Some viruses of pinnipeds were tentatively classified as new members of the genus Parapoxvirus, based on the partial sequence of the viral envelope gene and on phylogenetic analysis (Kennedy-Stoskopf 2001, Becher et al. 2002, Bracht et al. 2006). In some aquaria in Japan, poxviruses have been detected, using electron microscopy, in South American sea lions Otaria byronia (Okada \& Fujimoto 1984), bottlenose dolphins, and Pacific 
white-sided dolphins (Kohyama et al. 2010). However, the genetic relationship between parapoxviruses in both pinnipeds and cetaceans in Japan and those in other countries remains unclear. In this study, we performed sequence analysis and molecular characterization of parapoxvirus isolated from nodular lesions from a spotted seal Phoca largha in Japan.

\section{MATERIALS AND METHODS}

\section{Sample collection}

In March 2010, a 1-year-old, $26.5 \mathrm{~kg}$ female spotted seal Phoca largha showing nodular and scab lesions on the back and flippers was transported to an aquarium in Nagoya, Japan (Fig. 1). Three nodules on the back and flippers were collected by scratching with curettes and swabbing with a BD BBL Culture Swab kit (BD Japan). Serum was also collected for the virus-neutralizing $(\mathrm{VN})$ test.

\section{VN test}

Large numbers of seals all over the world have reportedly died from infection with phocine distemper virus (PDV) or canine distemper virus (CDV; Osterhaus et al. 1990b, Have et al. 1991, Barrett et al. 1992), and thus PDV or CDV infection is considered a highmortality threat to marine mammals. Both viruses are cross-reactive and closely related to each other. Thus the VN test against CDV was carried out using the serum sample and CDV KDK-1 strain (Mochizuki et al. 1999) as described in Nakano et al. (2009).

\section{DNA extraction and polymerase chain reaction}

DNA was extracted from the collected nodules and swabs from 3 different lesions using a DNeasy tissue kit (QIAGEN) according to the manufacturer's instructions; it was then used for the polymerase chain reaction (PCR). The PCR primers, North American consensus sequence primers 1 and 2 (NACP1/ NACP2) and Eurasian-African consensus sequence primers 1 and 2 (EACP1/EACP2) were used for the detection of the orthopoxvirus hemagglutinin (HA) gene (Ropp et al. 1995). The Pan-parapoxvirus primers 1 and 4 (PPP-1/PPP-4; Inoshima et al. 2000), as well as orf virus B2L F1 and R2 (OVB2LF1/ OVB2LR2; Hosamani et al. 2006), Envelope F/Enve-
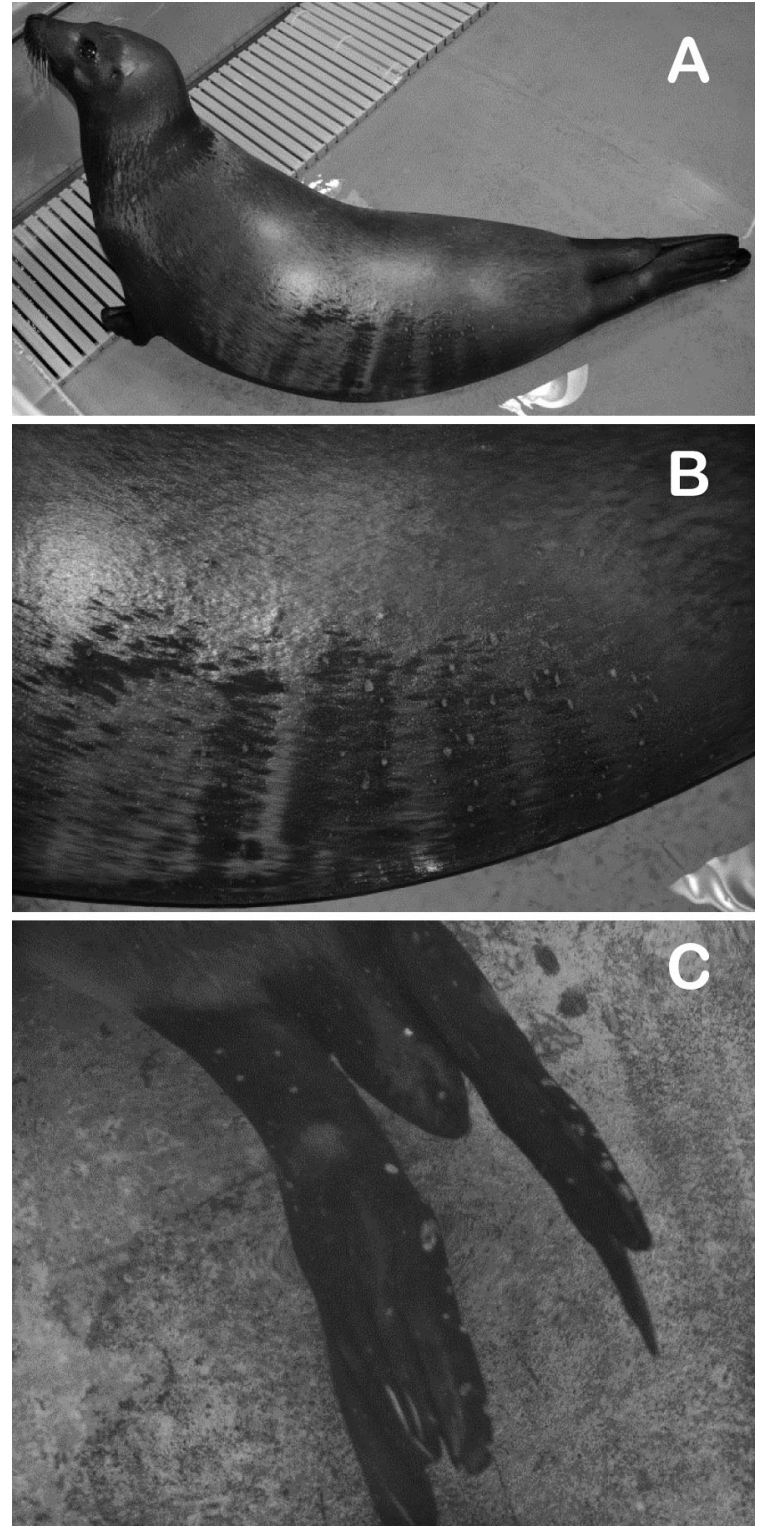

Fig. 1. Phoca largha. (A) Nodular lesions on body surface, (B) expanded image of body surface lesions, and (C) lesions on flippers

lope $\mathrm{R}$, and virus interferon resistance $\mathrm{F}$ and $\mathrm{R}$ (VIR F/VIR R; Guo et al. 2004) primer sets were used for the detection of the partial or full-length major envelope antigen gene, or virus interferon resistance (VIR) gene of parapoxvirus, respectively (Table 1).

\section{Sequence and phylogenetic analyses}

A partial nucleotide sequence of the envelope gene (554 bp) was determined from the amplified $594 \mathrm{bp}$ PCR product by direct sequencing using an ABI 310 
Table 1. Phoca largha. Primers used for polymerase chain reaction. NACP: North American consensus sequence primer; EACP: Eurasian-African consensus sequence primer; PPP: pan-parapoxvirus primer; OVB2L: orf virus B2L; VIR: virus interferon resistance

\begin{tabular}{|c|c|c|c|}
\hline Primers & Target & Sequence ( $5^{\prime}$ to $\left.3^{\prime}\right)$ & Source \\
\hline \multicolumn{4}{|c|}{ Orthopoxvirus } \\
\hline NACP1 & \multirow[t]{2}{*}{ Hemaggulutinin } & ACG ATG TCG TAT ACT TTG AT & \multirow[t]{2}{*}{ Ropp et al. (1995) } \\
\hline NACP2 & & GAA ACA ACT CCA AAT ATC TC & \\
\hline EACP1 & \multirow{2}{*}{ Hemaggulutinin } & ATG ACA CGA TTG CCA ATA C & \multirow[t]{2}{*}{ Ropp et al. (1995) } \\
\hline EACP2 & & CTA GAC TTT GTT TTC TG & \\
\hline \multicolumn{4}{|c|}{ Parapoxvirus } \\
\hline PPP-1 & Envelope & GTC GTC CAC GAT GAG CAG CT & \multirow{2}{*}{ Inoshima et al. (2000) } \\
\hline PPP-4 & & TAC GTG GGA AGC GCC TCG CT & \\
\hline OVB2LF1 & \multirow[t]{2}{*}{ Envelope } & TCCCTGAAGCCCTATTATTTTTGTG & \multirow[t]{2}{*}{ Hosamani et al. (2006) } \\
\hline OVB2LR2 & & GCTTGCGGGCGTTCGGACCTTC & \\
\hline Envelope F & \multirow[t]{2}{*}{ Envelope } & TTAATTTATTGGCTTGCAGAACTCCGAGCGC & \multirow[t]{2}{*}{ Guo et al. (2004) } \\
\hline Envelope R & & ATGTGGCCGTTCTCCTCCATC & \\
\hline VIR F & \multirow[t]{2}{*}{ Virus interferon resistance } & TTAGAAGCTGATGCCGCAG & \multirow[t]{2}{*}{ Guo et al. (2004) } \\
\hline VIR R & & ACAATGGCCTGCGAGTG & \\
\hline
\end{tabular}

DNA sequencer (Applied Biosystems) with a BigDye Terminator ver. 3.1 Cycle Sequencing kit (Applied Biosystems). The sequence was obtained from both strands for verification. Phylogenetic analysis was performed using the neighbor-joining method, and a tree was constructed using MEGA5 software (Tamura et al. 2011) with bootstrap values calculated from 1000 replicates.

\section{RESULTS}

\section{VN test}

VN antibody against CDV was not detected in the serum (data not shown), indicating that this individual was not infected with CDV or PDV.

\section{PCR}

No HA gene-specific fragment was amplified by the NACP1/NACP2 primers or the EACP1/EACP2 primers (data not shown), indicating that the nodules and scab lesions were not caused by an orthopoxvirus. In addition, specific DNA was not amplified either by the Envelope F/Envelope R primers for the full-length envelope gene or by the VIR F/VIR $R$ primers for the VIR gene of parapoxvirus (data not shown). Only the primers for the partial envelope gene of parapoxvirus, PPP-1 and PPP-4, amplified DNA from 2 of the 3 nodule samples and one of the 3 swab samples (data not shown).

\section{Sequence and phylogenetic analyses}

The sequence of the PCR product from the PPP-1 and PPP-4 primers was then determined. The determined sequence was seen to be closely related to 2 parapoxvirus strains from spotted seals Phoca largha (AY780676 and DQ073805), showing 99.8\% and $100 \%$ homology at the nucleotide and amino acid levels, respectively (Figs. $2 \& 3$, Table 2). Thus both the sequence and phylogenetic analyses revealed that the viral DNA in the lesions originated from pinniped parapoxvirus, and that infection with this virus was likely responsible for the lesions. We designated the virus as pinniped parapoxvirus strain Nagoya. The sequence has been deposited in DDBJ/EMBL/ GenBank under accession no. AB571081.

\section{DISCUSSION}

Of the various sets of primers for parapoxvirus, only the pair of primers for the partial envelope gene (PPP-1 and PPP-4) proved capable of amplifying an appropriately sized DNA fragment from the lesions. The primers for the full-length envelope and VIR genes proved incapable of amplifying any fragments. These primers were designed for the detection of orf virus, a member of the genus Parapoxvirus (Guo et al. 2004, Hosamani et al. 2006), which is the prototype of parapoxvirus and maintained mainly in sheep and goats. In contrast, the PPP-1/PPP-4 primer pair was designed for the detection of all parapoxvirus members (Inoshima et 


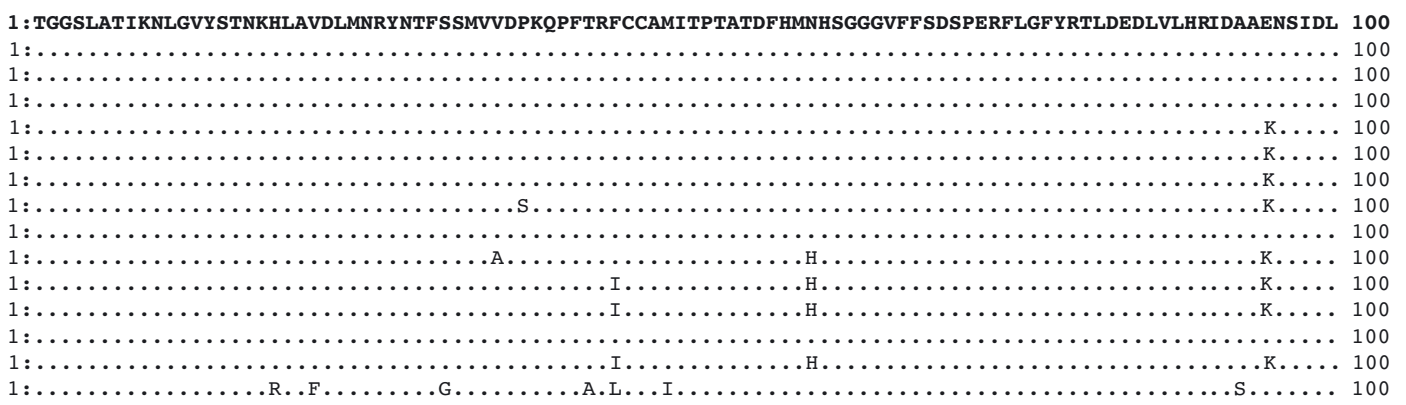

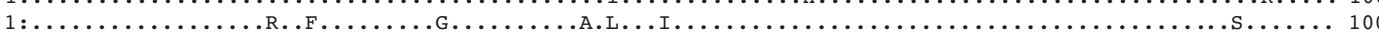

Spotted seal Nagoya Spotted seal Spotted seal Harbor seal

Harbor seal Harbor seal Harbor seal Harbor seal Grey seal

Steller sea lion Steller sea lion Steller sea lion California sea lion California sea lion California sea lion
(AB57 1081
(AY780676) (D0073805) (DQ273136) (DQ273135) (DQ219804) (AY952937) (AF414182) (DQ273134) (AY952946) (AY952940) (DQ163058) (DQ2731

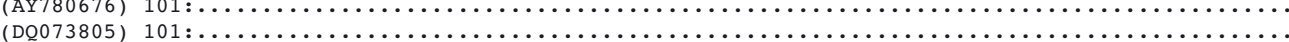



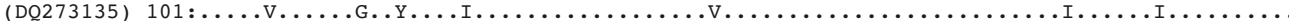

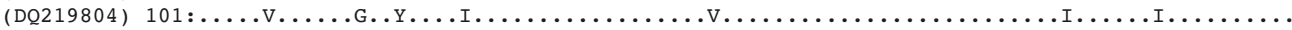

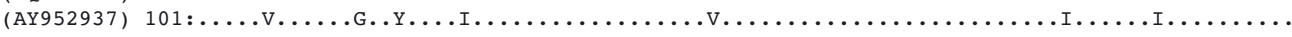

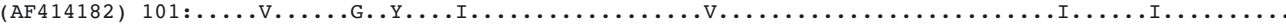



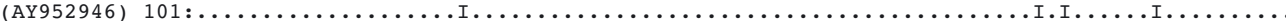

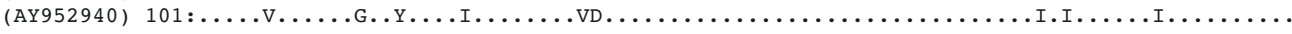

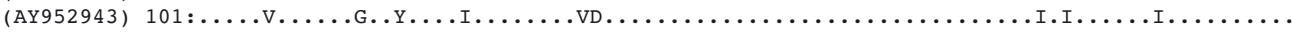



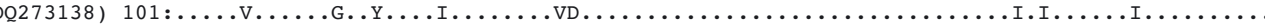

Fig. 2. Phoca largha. Comparison of deduced amino acid sequence of the viral envelope gene of the Nagoya strain with corresponding sequences of the parapoxviruses from various seal and sea lion species. Dots = consensus amino acids. Amino acid residues that are different from the Nagoya strain are shown

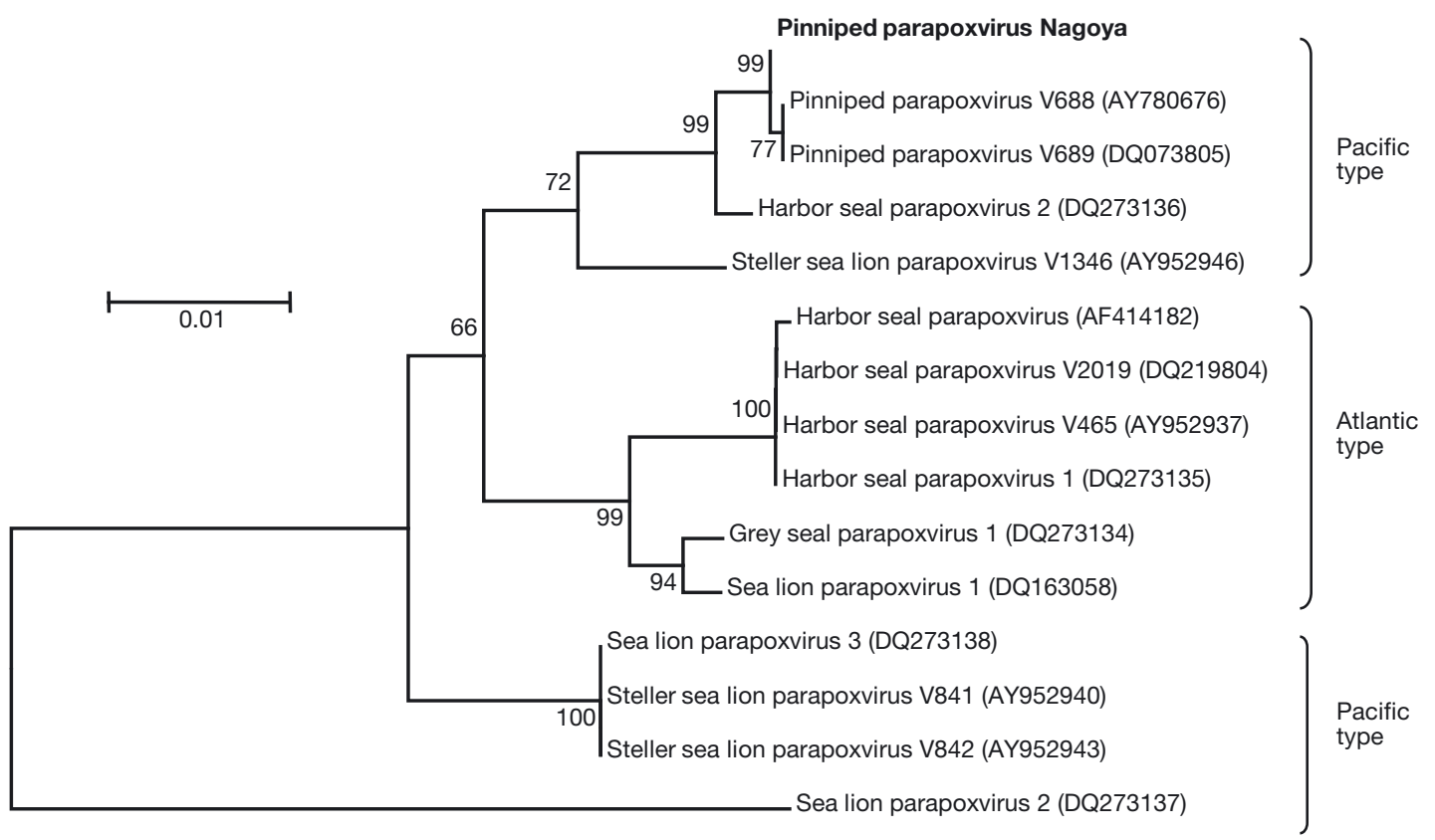

Fig. 3. Phoca largha. Phylogenetic relationships based on nucleotide sequence of the viral envelope gene of the Nagoya strain with corresponding sequences of the parapoxviruses. Tree was constructed by neighbor-joining method using MEGA5 software, with bootstrap values calculated from 1000 replicates. All bootstrap values are displayed above the tree branches. The

Nagoya strain is shown in bold

al. 2000). Although the combination of PCR analysis and serological tests with virus isolation and/or electron microscopy would be a more accurate and reliable method for diagnosis, our results suggest that the PPP-1/PPP-4 primer pair is extremely useful for the PCR diagnosis of parapoxvirus infection in not only domestic and wild ruminants but also in marine mammals. Importantly, PCR analysis can be rapidly and easily performed for a wide variety of animal species in zoos and aquariums. 
Table 2. Phoca largha. Sequence identity with Nagoya strain at nucleotide and amino acid levels

\begin{tabular}{|c|c|c|c|c|}
\hline Host & $\begin{array}{l}\text { Habitat } \\
\text { area }\end{array}$ & $\begin{array}{l}\text { Accession } \\
\text { no. }\end{array}$ & $\begin{array}{c}\text { Sequence identity (\%) with } \\
\text { Nucleotide levels } \\
\text { (554 bp) }\end{array}$ & $\begin{array}{l}\text { Nagoya strain (AB571081) } \\
\text { Amino acid levels } \\
\text { (184 aa) }\end{array}$ \\
\hline Spotted seal Phoca largha & Pacific Ocean & $\begin{array}{l}\text { AY780676 } \\
\text { DQ073805 }\end{array}$ & $\begin{array}{l}99.8 \\
99.8\end{array}$ & $\begin{array}{l}100.0 \\
100.0\end{array}$ \\
\hline Harbor seal $P$. vitulina richardii & Pacific Ocean & DQ273136 & 98.7 & 98.9 \\
\hline Harbor seal $P$. vitulina concolor & Atlantic Ocean & $\begin{array}{l}\text { DQ273135 } \\
\text { DQ219804 } \\
\text { AY952937 }\end{array}$ & $\begin{array}{l}92.7 \\
92.7 \\
92.7\end{array}$ & $\begin{array}{l}95.6 \\
95.6 \\
95.6\end{array}$ \\
\hline Harbor seal $P$. vitulina vitulina & Atlantic Ocean & AF414182 & 92.5 & 95.1 \\
\hline Grey seal Halichoerus grypus & & DQ273134 & 93.6 & 96.1 \\
\hline Steller sea lion Eumetopias jubatus & Pacific Ocean & $\begin{array}{l}\text { AY952946 } \\
\text { AY952940 } \\
\text { AY952943 }\end{array}$ & $\begin{array}{l}95.6 \\
90.7 \\
90.7\end{array}$ & $\begin{array}{l}96.1 \\
93.4 \\
93.4\end{array}$ \\
\hline $\begin{array}{l}\text { California sea lion } \\
\text { Zalophus californianus }\end{array}$ & Pacific Ocean & $\begin{array}{l}\text { DQ163058 } \\
\text { DQ273138 } \\
\text { DQ273137 }\end{array}$ & $\begin{array}{l}93.5 \\
90.7 \\
84.4\end{array}$ & $\begin{array}{l}95.6 \\
93.4 \\
92.3\end{array}$ \\
\hline
\end{tabular}

Two parapoxviruses from spotted seals Phoca largha in Alaska (AY780676 and DQ073805) showed $100 \%$ homology with this new Nagoya strain at the amino acid level. The spotted seal habitat extends from the Bering Sea to the Japan Sea, and genetically closely related parapoxviruses may therefore spread or be maintained in this habitat range or population of spotted seals. Phylogenetic analysis demonstrated that 3 parapoxviruses from spotted seals were part of the same cluster, with one parapoxvirus (DQ273136) from the harbor seal and one (AY952946) from the Steller sea lion. The parapoxviruses in this cluster are from pinnipeds, whose habitat is the Pacific ocean. Other clusters were mostly constructed by viruses detected from pinnipeds from either the Pacific or the Atlantic Oceans. Therefore, it is conceivable that although sea lion parapoxvirus 1 (DQ163058) was categorized into the same cluster as grey seal parapoxvirus 1 (DQ273134), parapoxviruses in pinnipeds may be genetically classified into 2 types related by their habitat, i.e. Pacific or Atlantic types. As mentioned by Nollens et al. (2006a, 2006b), Atlantictype parapoxvirus may be introduced into Pacific pinnipeds, and vice versa, via indirect contact with infected Arctic ice seals, including ringed seals $P$. hispida and bearded seals Erignathus barbatus, which are found in both the Atlantic and Pacific oceans. Further analysis is needed to clarify this issue.

Some parapoxviruses from seals and sea lions are zoonotic, giving rise to cutaneous infections on the fingers and hands of people who handle infected animals (Hicks \& Worthy 1987, Clark et al. 2005), and necessitating the use of gloves in during such handling (Kennedy-Stoskopf 2001).
To date, veterinarians and staff at aquariums have called the pox-like disease in pinnipeds 'sealpox'. However, the disease, as in the present case, is caused by parapoxvirus, not orthopoxvirus. There is only one report of skin lesions caused by an orthopoxvirus infection in pinnipeds, although no sequence characterization has been reported (Osterhaus et al. 1990a). A poxvirus from a Steller sea lion was found to be distinct from the genus Parapoxvirus; phylogenetic analysis found it to be more closely related to, but clearly distinct from, Orthopoxvirus (Burek et al. 2005, Bracht et al. 2006). Therefore, although the causative virus, parapoxvirus or orthopoxvirus, cannot be identified until virological tests are carried out, 'sealpox' would be most likely caused by parapoxvirus.

Acknowledgements. This study was partly supported by a Grant-in-Aid for Scientific Research and by the Special Coordination Fund for Promoting Science and Technology from the Ministry of Education, Culture, Sports, Science, and Technology, Japan. This study was also supported in part by a special grant from the Research Center for Wildlife Management, Gifu Universiy, Japan

\section{LITERATURE CITED}

Barrett T, Blixenkrone-Møller M, Domingo M, Harder T and others (1992) Round table on morbilliviruses in marine mammals. Vet Microbiol 33:287-295

Becher P, König M, Müller G, Siebert U, Thiel HJ (2002) Characterization of sealpox virus, a separate member of the parapoxviruses. Arch Virol 147:1133-1140

Bracht AJ, Brudek RL, Ewing RY, Manire CA and others (2006) Genetic identification of novel poxviruses of cetaceans and pinnipeds. Arch Virol 151:423-438 
Burek KA, Beckmen K, Gelatt T, Fraser W, Bracht AJ, Smolarek KA, Romero CH (2005) Poxvirus infection of Steller sea lions (Eumetopias jubatus) in Alaska. J Wildl Dis 41: 745-752

Clark C, Mclntyre PG, Evans A, Mclnnes CJ, Lewis-Jones S (2005) Human sealpox resulting from a seal bite: confirmation that sealpox virus is zoonotic. Br J Dermatol 152: 791-793

Damon IK (2007) Poxviruses. In: Knipe DM, Howley PM (eds) Fields virology, 5th edn. Lippincott, Williams \& Wilkins, Philadelphia, PA, p 2947-2975

Gulland FMD, Haulena M, Dierauf LA (2001) Seals and sea lions. In: Dierauf LA, Gulland FMD (eds) CRC handbook of marine mammal medicine, 2nd edn. CRC Press, Boca Raton, FL, p 907-926

Guo J, Rasmussen J, Wünschmann A, de La ConchaBermejillo A (2004) Genetic characterization of orf viruses isolated from various ruminant species of a zoo. Vet Microbiol 99:81-92

Have P, Nielsen J, Bøtner A (1991) The seal death in Danish waters 1988. 2. Virological studies. Acta Vet Scand 32: 211-219

Hicks BD, Worthy GAJ (1987) Sealpox in captive grey seals (Halichoerus grypus) and their handlers. J Wildl Dis 23: $1-6$

Hosamani M, Bhanuprakash V, Scagliarini A, Singh RK (2006) Comparative sequence analysis of major envelope protein gene (B2L) of Indian orf viruses isolated from sheep and goats. Vet Microbiol 116:317-324

Inoshima Y, Morooka A, Sentsui H (2000) Detection and diagnosis of parapoxvirus by the polymerase chain reaction. J Virol Methods 84:201-208

Kennedy-Stoskopf S (2001) Viral diseases. In: Dierauf LA Gulland FMD (eds) CRC handbook of marine mammal medicine, 2nd edn. CRC Press, Boca Raton, FL, p 285-307

Kohyama K, Nakajima M, Hashimoto A, Okada K (2010) Poxvirus infection in bottle-nosed dolphins, Tursiops truncates and Pacific white-sided dolphins, Lagenorhynchus obliquidens. J Jpn Assoc Zoo Aqua 51:9-14 (in Japanese)

Mochizuki M, Hashimoto M, Hagiwara S, Yoshida Y, Ishiguro S (1999) Genotypes of canine distemper virus determined by analysis of the hemagglutinin genes of recent

Editorial responsibility: Michael Moore, Woods Hole, Massachusetts, USA isolates from dogs in Japan. J Clin Microbiol 37: 2936-2942

Müller G, Gröters S, Siebert U, Rosenberger T and others (2003) Parapoxvirus infection in harbor seals (Phoca vitulina) from the German North Sea. Vet Pathol 40: 445-454

Nakano H, Kameo Y, Sato H, Mochizuki M and others (2009) Detection of antibody to canine distemper virus in wild raccoons (Procyon lotor) in Japan. J Vet Med Sci 71: 1661-1663

Nettleton PF, Munro R, Pow I, Gilray J, Gray EW, Reid HW (1995) Isolation of a parapoxvirus from a grey seal (Halichoerus grypus). Vet Rec 137:562-564

- Nollens HH, Jacobson ER, Gulland FMD, Beusse DO and others (2006a) Pathology and preliminary characterization of a parapoxvirus isolated from a California sea lion (Zalophus californianus). J Wildl Dis 42:23-32

> Nollens HH, Gulland FMD, Jacobson ER, Hernandez JA, Klein PA, Walsh MT, Condit RC (2006b) Parapoxviruses of seals and sea lions make up a distinct subclade within the genus Parapoxvirus. Virology 349:316-324

> Okada K, Fujimoto Y (1984) The fine structure of cytoplasmic and intranuclear inclusions of seal pox. Jpn J Vet Sci 46:401-404

> Osterhaus ADME, Broeders HWJ, Visser IKG, Teppema JS, Vedder EJ (1990a) Isolation of an orthopoxvirus from pox-like lesions of a grey seal (Halichoerus grypus). Vet Rec 127:91-92

> Osterhaus ADME, Groen J, Spijkers HEM, Broeders HWJ and others (1990b) Mass mortality in seals caused by a newly discovered virus-like morbillivirus. Vet Microbiol 23:343-350

Ropp SL, Jin QI, Knight JC, Massung RF, Esposito JJ (1995) PCR strategy for identification and differentiation of smallpox and other orthopoxviruses. J Clin Microbiol 33: 2069-2076

Tamura K, Peterson D, Peterson N, Stecher G, Nei M, Kumar S (2011) MEGA5: Molecular evolutionary genetics analysis using maximum likelihood, evolutionary distance, and maximum parsimony methods. Mol Biol Evol 28: 2731-2739

Tryland M, Klein J, Nordøy ES, Blix AS (2005) Isolation and partial characterization of a parapoxvirus isolated from a skin lesion of a Weddell seal. Virus Res 108:83-87

Submitted: February 23, 2011; Accepted: August 22, 2011

Proofs received from author(s): October 29, 2011 